\title{
The Effect of Problem Based Learning Model and Creative Thinking Ability on Student's Problem Solving Ability
}

\author{
Sahyar Sahyar, Rizki Noveri \\ Physics Education Department \\ Postgraduate of State University of Medan, \\ Medan, Indonesia \\ Corresponding author: sahyar@unimed.ac.id
}

\begin{abstract}
This research aimed to analyze: the effect of problem based learning model on student's problem solving ability; the effect of creative thinking ability on student's problem solving ability and interaction between learning model and creative thinking ability in increasing student's problem solving ability. This research was a quasi-experimental design with two group pre-test post-test design. Experimental group taught by problem based learning model consist of 40 students and control group taught by conventional learning consist of 40 students. The data were analyzed by two ways of variances. Statistical test with 0.05 significant levels showed that: student's problem solving ability that taught by problem based learning model were greater than the conventional learning; problem solving ability group of students that have high creative thinking ability were greater than the students that have low creative thinking ability; there were interaction between learning model and creative thinking ability in increasing student's problem solving ability; the role of creative thinking ability in increasing student's problem solving ability on experimental group were greater than on control group.
\end{abstract}

Keywords- Problem Based Learning Model; Creative Thinking Ability; Problem Solving Ability

\section{INTRODUCTION}

The main purpose of physics learning in senior high school is to solve the problem in daily life using concept and theory of physics. Furthermore, the objective of revised curriculum 2013 is to make students have higher order thinking skill (HOTS). HOTS is a process of thinking, not just memorize and convey the information. HOTS is the ability to connect, manipulate, and transform the existing knowledge and experience to creative thinking in making decisions and solving problems in new situations. HOTS is an important thing that can be applied in the learning process, including physics learning. The implementation of HOTS in learning will make students to be used to analyze, justify and creatively in solving problems found in daily life. Learning physics is also one of the efforts to achieve education goals that can educate the life of the nation. In the process of learning physics, students can see directly the physics phenomenon to grow their curiosity. From curiosity, students can be motivated to learn physics as in [1].

Facts in several high schools in Indonesia state that students still have low order thinking skills. Generally, the ability of senior high school students in solving problem in physics is still low. The indicator of lowest achievement of students shows by the ability in solving high order thinking problem is still low. Result of TIMMS (Trend of International on Mathematics and Science Study) shows that scientific achievement of students in Indonesia is still low compared to the other country in ASIA as in [2]. TIMMS standard test in not only measure question solving ability, but also measure students problem solving ability (PSA), analyze it, and communicate their opinion to others.

The low ability of physics problem solving of high school students caused by many factors, such as the application of learning model that has not been in accordance to the purpose of learning. The problem based learning (PBL) model is a learning approach that uses real life problems as a context for students to learn about critical thinking and PSA, and to acquire essential knowledge and concepts from the subject matter. The core of PBL is the presenting the authentic and meaningful problem situation to students that can be the basis of the investigation as in [3]. Implementing of problem solving in the learning process is important, because in addition to trying to answer questions or solve problems, students are also motivated to work hard. In addition to developing PSA, PBL models also emphasize the achievement of high-level competencies of critical thinking, creative, and productive. The PBL model is the appropriate learning model in improving the PSA of high school students.

To improve the effectiveness of PBL model, it is necessary to consider other variables that can affect PSA. Students learning outcomes are not only influenced by the learning model but influenced by other important variables such as creative thinking ability (CTA) that can influence students learning outcomes as in [4]. The ability to think creatively is an individual mental process that produces effective, imaginative, aesthetic, flexible, integration, succession, and 
effective differentiation in various fields to solve a problem as in [5]. CTA is needed by every individual to face the inevitable new changes in life. In learning activities, creative group students are better to find problems and to solve problems [6]. The students CTA has a great influence in optimizing students thinking processes [7]. This research used CTA variable as moderator to test whether the CTA can support PBL model in improving PSA in physics study.

\section{LITERATURE REVIEW}

PBL is one of learning models designed primarily to help students develop their thinking, problem solving and intellectual abilities, learn the roles of adults by experiencing them through simulated real situations, and become independent and autonomous learners [3]. So, PBL model is able to grow HOTS. The essence of PBL model is learning based on problems that require authentic and real investigation as in [5]. Characteristics of PBL are 1) Asking questions or problems, creating questions related to the problem and enabling the emergence of various solutions to solve the problem. 2) Focusing on interdisciplinary linkages, students review the issues from different subjects. 3) Authentic inquiry, students must analyze, establish problems, develop hypotheses and make predictions, collect and analyze information, carry out experiments and draw conclusions. 4) Produce products and publish, demanding learners to produce certain products in form of real work or demonstrations that represent the solution of problems they find. 5) Collaboration, students work together, most commonly forming pairs in small groups. Work together to motivate continuously in more complex assignments and improve the development of social skills [5].

The steps of PBL model as in [3]: (1) orient students to the problem; (2) Organize students for study; (3) Assist independent and group investigations; (4) Develop and present artifacts and exhibit; (5) Analyze and evaluate the problem solving process. The advantages of the PBL model is able to train students to use various concepts, principles and skills they have learned to solve the problems that are faced as in [5]. Learning theory that is in line with the PBL model is social constructivism theory from Vigotsky and learning theory from Bruner that is learned through discovery.

Conventional learning (CL) is learning that usually used by teacher in teaching as in [8]. In CL, teachers seem to be more active as motivators of knowledge about subject matter and methods generally used are lecture methods with question and answer, demonstration, discussion and assignment so that students are less active in getting information or concepts as learning objectives.

Problems can be defined as the difference between the results to be achieved with the existing reality. In general, a problem is a situation that meets the following requirements: 1) the situation indicates a gap between expectations and reality, 2) the situation generates motivation to find a solution and 3 ) there is no quick way to use it solve the problem. The problem solving stage in science consists of five stages as in [9]. This step will help in problem solving so it is easier to interpret and follow. The five stages of problem solving are: 1) problem visualization; 2) describe the problem in terms of physics; 3) plan solutions; 4) implement the solution plan; 5) Check and evaluate solutions.

Creativity is an ability to think about things in new ways to achieve unusual and unique solutions in problems. Father of creativity research stated that what makes creativity is people effort to solve problems. There are four elements of creativity namely a fluid structure, flexibility, originality and skills to incorporate as in [10].

The ability to think creatively is the ability of individuals to offer new solutions or more than one solution or combination of methods to solve a problem. CTA are operationally defined as a process that reflected in fluency, flexibility, and originality in thinking as in [11]. The students CTA will positively affect the students PSA. The combination between implementing PBL models and good students CTA will improve PSA optimally.

The students CTA has a positive effect on PSA, because in solving problem, students must be creative in offering more than one solution and choose the most efficient and effective solution in solving the problems faced.

Previous research has generally proved that the PBL model is better in improving PSA in various fields of study, but the average grade achieved by students using the PBL model is generally in sufficient category. By considering the variables of creative thinking is expected to solve problems of students in the field of Physics study can be more increased.

The results of study of the PBL model of research as follows which analyzes the effect of problem-based learning and AQ to the high-level thinking skills and conceptual understanding of physics as in [12]. To investigate the effects of problem-based learning on pre-service teachers' critical thinking dispositions and perceptions of PSA as in [13]. Using the model PBL can improve understanding of concepts and PSA of physics as in [14]. There is the impact of problembased learning on students attitude toward science, PSA and sense of community in the classroom as in [15].

From the experiment showed that the students ability level has significant influence on problem solving task competence, that means there is an increasing of students PSA in discussion as in [16]. This implies that, all the students in the different ability levels were able to solve problems and its prerequisite concepts. It states that even the ability of students is different, but when they trait by PBL, the Students PSA will be increase. In this research found that there a significant relationship between teaching learning and problem solving task in physics. In this research found that there is a significant impact on teaching learning in physics. In other research found that PBL is an effective strategy to use in the classroom, especially regarding students engagement, means that PBL model is an effective learning model, especially in increasing physics learning outcomes of students as in [17]. From a research found that more than $95 \%$ admitted that they have gained from PBL, especially on the generic skills, and were willing to take other classes that implements PBL in the future, that means more than $95 \%$ students admitted that they obtained positive impact of PBL and want to try to use it in other subject [18]. 


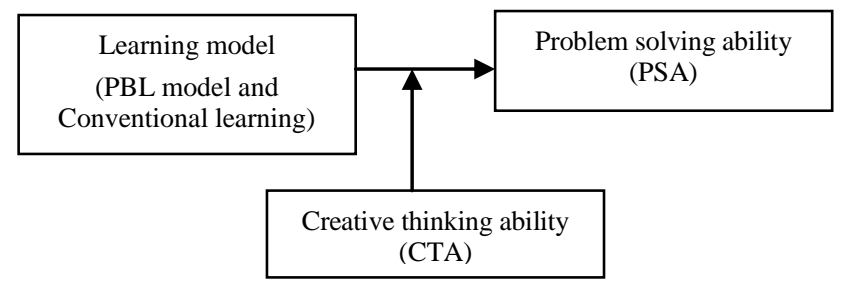

Fig. 1. Conceptual Framework

The different of this research between the earlier researches is to find the interaction of PBL Model and CL with Creative thinking as moderator in increasing the PSA. The conceptual framework is described in the figure above.

\section{METHOD}

This research was a quasi-experimental research with two group pre-test and post-test design. The population of this research was second semester of class $X$ in academic year 2016/2017 at SMA Negeri 3 Medan that consist of eleven classes and 460 students. The sample of this research were two classes that consist of 80 students by using class random sampling technique. Class $\mathrm{X}-\mathrm{A}$ was experimental group taught by PBL model, class X-B was control group taught by CL. Variables of this research consisted of independent, moderator and dependent variable. The independent variable was learning model. The moderator variable was CTA. The dependent variable was PSA. The treatment instruments were lesson plan, handout, and students handbook. Measurement instruments consisted of valid essay test of CTA and PSA that fulfilled validity and reliability requirements. The CTA indicators consisted of influence, flexibility, original and elaboration. PSA indicators consisted of five aspects namely: visualize the problem, describe the problem in physics description, plan the solution, execute the plan and check and evaluate. The material was essay test of temperature and heat for second semester of class $\mathrm{X}$. The data were analyzed by using prerequisite and hypothesis test. The normality test analyzed by Kolmogorov-Smirnov Test. The homogeneity test analyzed by Levene's Test of equality error variance. Hypothesis test were analyzed by using F-test variance two ways with the level of significance 0.05 . The design of research given on Table I.

TABLE I. Two Group PreteTs-Postest DESIGN

\begin{tabular}{|l|l|l|l|}
\hline \multicolumn{1}{|c|}{ Group } & Pre-test & Treatmen & Post-test \\
\hline $\begin{array}{l}\text { Experimental group ( PBL } \\
\text { model) }\end{array}$ & $\mathrm{T}_{1}$ & $\mathrm{X}$ & $\mathrm{T}_{2}$ \\
\hline $\begin{array}{l}\text { Control group (conventional } \\
\text { learning) }\end{array}$ & $\mathrm{T}_{1}$ & 0 & $\mathrm{~T}_{2}$ \\
\hline
\end{tabular}

\section{Explanation:}

$\mathrm{T} 1=$ Pre-test

$\mathrm{T} 2=$ Post-test

$\mathrm{X}=$ Treatment by using PBL model

$0=$ Treatment by using conventional
TABLE II. ANALYZE OF VARIANCE TWO WAYS

\begin{tabular}{|l|l|l|l|}
\hline \multicolumn{1}{|c|}{ PSA } & \multicolumn{2}{|c|}{$\begin{array}{c}\text { Problem solving ability } \\
\text { (PSA) }\end{array}$} & \multirow{2}{*}{ Mean } \\
\cline { 1 - 3 } CTA & $\begin{array}{c}\text { Conventional } \\
\text { class }\left(\boldsymbol{A}_{1}\right)\end{array}$ & $\begin{array}{c}\text { PBL class } \\
\left(\boldsymbol{A}_{2}\right)\end{array}$ & \\
\hline Low CTA $\left(\mathrm{B}_{1}\right)$ & $\mu \mathrm{A} 1 \mathrm{~B} 1$ & $\mu \mathrm{A} 2 \mathrm{~B} 1$ & $\mu \mathrm{B} 1$ \\
\hline High CTA $\left(\mathrm{B}_{2}\right)$ & $\mu \mathrm{A} 1 \mathrm{~B} 2$ & $\mu \mathrm{A} 2 \mathrm{~B} 2$ & $\mu \mathrm{B} 2$ \\
\hline Mean & $\mu \mathrm{A} 1$ & $\mu \mathrm{A} 2$ & \multicolumn{1}{|c|}{} \\
\cline { 1 - 2 } & \multicolumn{2}{|l}{} &
\end{tabular}

Explanation:

$\mu \mathrm{A} 1 \mathrm{~B} 1$ : Mean of students PSA on conventional class who have low CTA

$\mu \mathrm{A} 1 \mathrm{~B} 2$ : Mean of students PSA on conventional class who have high CTA

$\mu \mathrm{A} 2 \mathrm{~B} 1$ : Mean of students PSA on PBL class who have low CTA

$\mu \mathrm{A} 2 \mathrm{~B} 2$ : Mean of students PSA on PBL class who have high CTA

$\mu \mathrm{A} 1 \quad$ : Mean of students PSA on conventional class

$\mu \mathrm{A} 2 \quad$ : Mean of students PSA on PBL class

$\mu \mathrm{B} 1 \quad$ : Mean of students PSA who have low CTA

$\mu \mathrm{B} 2 \quad$ : Mean of students PSA who have high CTA

The data analyzed by two ways analyses of variance were given on Table II.

\section{RESULT}

Students PSA on the Conventional class and PBL class show on following table.

Based on Table III, description of the average value of pretest and posttest PSA on the PBL and conventional class as follows: For each class pre-test conventional and PBL are 40.75 and 39.12 in the low category. For each class post-test conventional and PBL are 50.92 and 71.12 in medium and high category.

The Results of post-test students physics PSA on the Conventional and PBL class that have low and high CTA show on following Table IV.

Table IV shows that maximum average of students PSA is 75.00 on PBL class that have high CTA. Minimum average of students PSA is 49.04 on CL class that have low CTA.

\section{A. Hypothesis testing}

Before testing the hypothesis, first tested the prerequisite such as normality test, homogeneity test, and test of results normal distribution and homogeneous data. After the prerequisite test is done, and then followed with two ways ANOVA with SPSS software.

TABLE III. PRE TEST AND POST TEST PROBLEM SOlVING ABILITY

\begin{tabular}{|c|l|c|}
\hline \multirow{2}{*}{} & \multicolumn{2}{|c|}{ Problem solving ability/PSA } \\
\cline { 2 - 3 } & $\begin{array}{c}\text { Control class } \\
\text { (Conventional learning) }\end{array}$ & $\begin{array}{c}\text { Experiment class } \\
(\text { PBL model })\end{array}$ \\
\hline Pre- test & 40.75 & 39.12 \\
\hline Post-test & 50.92 & 71.12 \\
\hline
\end{tabular}


TABLE IV. POST TEST PROBLEM SOLVING ABILITY

\begin{tabular}{|c|c|c|c|}
\hline \multirow{3}{*}{$\begin{array}{c}\text { Creative } \\
\text { thinking } \\
\text { ability/CTA }\end{array}$} & \multicolumn{2}{|c|}{ Problem Solving Ability/PSA (A) } & \multirow{3}{*}{ Mean } \\
\hline & Conventional learning & PBL Model & \\
\hline & $(\mathbf{A 1})$ & (A2) & \\
\hline Low (B1) & 49.04 & 64.66 & 55.55 \\
\hline High (B2) & 53.00 & 75.00 & 65.50 \\
\hline Mean & 50.92 & 71.12 & \\
\hline
\end{tabular}

Based on Table $\mathrm{V}$, the results of the data analyze are as follows: (1) Students PSA taught by PBL model is better than the CL (sig 0,000<0,05), (2) Students PSA who have high creative thinking better than the students who have low creative thinking ( $\operatorname{sig} 0,000<0,05)$, and $(3)$ there is interaction between learning model (PBL model and CL) and CTA in influencing students PSA (sig 0,043<0,05).

In analyzing the difference between the groups then used the analyze of Post Hoc-Test with Scheffe test. The results presented in Table VI.

Based on Table VI obtained some comparisons interaction between groups as follows: 1) The PSA on CL for group of students who have low CTA was as same as the Students PSA on CL for group of students who have high CTA with significant $p>0.05,2$ ) PSA on PBL for group of students who have high CTA was higher than the Students PSA on PBL for group of students who have low CTA with significant $p<0.05$; 3) PSA on CL for group of students who have high CTA was less than the Students PSA on PBL for group of students who have high CTA with significant $\mathrm{p}<0.05,4)$ PSA on CL for groups of students low CTA was less than the Students PSA on PBL for groups low CTA with significant $\mathrm{p}<0.05$; 5) PSA on CL for groups of students high CTA was less than the Students PSA on PBL for groups low CTA with significant $\mathrm{p}<0.05$; 6) PSA on CL for groups of students low CTA was less than the Students PSA on PBL for groups high CTA with significant $p<0.05$. For more clearly in view as the interaction will be shown in Fig. 1.

The graph shows that on PBL class, students PSA who have high CTA are better than students PSA who have low CTA. On Conventional class, students PSA who have high creativity same as students PSA who have low creativity. The graph shows that the increasing of PSA between low and high CTA on PBL class was greater than on CL class. PSA optimum on PBL class for students who have high CTA.

TABLE V. PRE Test And Post Test PRoblem SOlVING ABILITy

\begin{tabular}{|l|l|l|l|l|l|}
\hline \multicolumn{1}{|c|}{ Result } & $\begin{array}{c}\text { Square } \\
\text { Sum }\end{array}$ & $\begin{array}{c}\text { Degree } \\
\text { of } \\
\text { freedom }\end{array}$ & $\begin{array}{c}\text { Square } \\
\text { Average }\end{array}$ & \multicolumn{1}{|c|}{ F } & Sig. \\
\hline Learning Model & 6839.41 & 1 & 6839.41 & 147.57 & 0.00 \\
\hline Creative thinking ability & 986.29 & 1 & 986.29 & 21.28 & 0.00 \\
\hline $\begin{array}{l}\text { Learning Model* } \\
\text { Creative thinking ability }\end{array}$ & 196.77 & 1 & 196.77 & 4.24 & 0.04 \\
\hline
\end{tabular}

TABLE VI. Post Hoc-Test

\begin{tabular}{|l|l|l|l|l|}
\hline \multirow{2}{*}{$\begin{array}{c}\text { Interaction } \\
\text { A }\end{array}$} & \multicolumn{1}{|c|}{ Interaction B } & $\begin{array}{c}\text { Mean } \\
\text { Difference } \\
\text { (A-B) }\end{array}$ & $\begin{array}{c}\text { Std. } \\
\text { Error }\end{array}$ & Sig. \\
\hline $\begin{array}{l}\text { CL for high } \\
\text { CTA }\end{array}$ & CL for low CTA & 4.05 & 2.16 & 0.328 \\
\hline $\begin{array}{l}\text { PBL model } \\
\text { for low } \\
\text { CTA. }\end{array}$ & CL for low CTA & $15.76^{*}$ & 2.33 & 0.000 \\
\cline { 2 - 5 } & CL for high CTA & $11.71^{*}$ & 2.33 & 0.000 \\
\hline PBL model for & CL for low CTA & $26.10^{*}$ & 2.05 & 0.000 \\
\cline { 2 - 6 } high CTA & CL for high CTA & $22.05^{*}$ & 2.05 & 0.000 \\
\cline { 2 - 6 } & PBL model for low CTA & $10.33^{*}$ & 2.23 & 0.000 \\
\hline
\end{tabular}

\section{DISCUSSION}

\section{A. Students poblem solving ability by using problem based learning model and conventional learning}

The result showed that the average gain of students PSA taught by PBL model was better than CL. The Students PSA taught by PBL model were in medium level. The Students PSA taught by CL were in low level. This showed that the Students PSA taught by PBL model ewas better than CL. It caused by PBL model that was characterized by the problems encountered in everyday life, so students widen their knowledge about what was known and how to solve problems in groups and collaborate each other in solving problems. This was in line with [14] stated that PBL model enhanced students PSA of physics problems. Furthermore, as in [19] and [1], showed that the average of post-test score of experimental group taught by PBL model was better than the control group taught by CL. In line with [14] stated that learning approach used real problems as a context to learn PSA and acquired essential knowledge and concepts. This allowed students to exchange ideas, work together to solve problems that can ultimately enhanced students physics PSA. In line [13] stated that PBL model had positive effect on students PSA thinking and perceptions. Moreover, teacher introduced different model from CL where the involvement in learning was unknown as a reason for low level of thinking ability, but in this process teachers were given the opportunity to develop students PSA in thinking and perception. The effect PBL model on another higher order thinking showed in research as in [1], [13], [14] and [19].

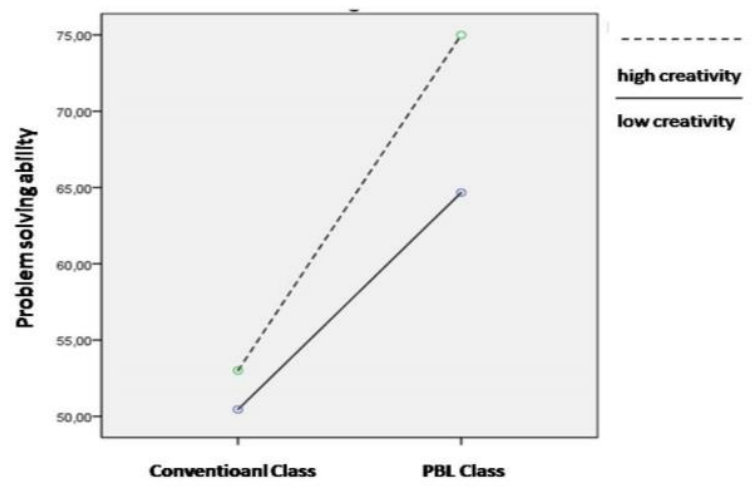

Fig. 2. Interaction Model of Learning and Creative Thinking ability on Problem solving ability 
Based on the explanation above, it was clear that the PBL model can improve students PSA in learning physics. In CL, teacher conveyed information directly to students by setting the time to achieve defined goals as efficiently as possible. So, CL reduced students opportunity to develop PSA.

\section{B. Students Problem solving ability and creative thinking ability}

Based on hypothesis testing that students PSA who have high CTA were better than students PSA who have low CTA. The findings of this research showed that the students CTA influenced students PSA in physics. The students that thinking creative have character in: a fluid structure, flexibility, originality and skills to incorporate. This character needs to solve a problem in daily life or physics subject. So, the students that have high level of creative thinking have high level of PSA. The ability to think creatively is important to improve PSA especially in data manipulation, controlling variables for research and to determine causal relationships in solving a problem.

The results of this research is in line with [7] that states students CTA is influence students learning outcomes. Reference [20] and [21] mentions that the ability of creative thinking has a positive effect on students learning outcomes. Furthermore, in line with research [22] explains that students who have high CTA is easier to find, understand and solve the problem when compared with students who have low CTA.

Based on theoretical studies and the results of research can be concluded that the creativity of students influences the achievement of high-learning results of students, such as the results of learning PSA. The better the CTA students then the result of learning PSA is better.

\section{Interaction between leraning model and creative thinking ability}

Based on hypothesis testing there was interaction between learning model and CTA for increasing the students physics PSA. Influence CTA toward students PSA on PBL class was higher than on CL class. Interaction between learning model and CTA provided an alternative potential to develop higher order thinking as in [23]. In the PBL class students level of creativity can function optimally because the PBL model students are faced with problem solving. In the conventional class of creativity is not functioning optimally because in the conventional class students are not faced with the problem so that the effect on the students PSA is low. This result is in line with research of as in [24], [25] and [26].

On PBL class, students PSA who have high CTA were better than students PSA who have low CTA. On conventional class, students who have high CTA were same as students PSA who have low CTA. This was due to students who have high CTA able to the ability of individuals to offer new solutions or offer more than one solution or combination of methods to solve a problem. Students who have low CTA lack of diligent and persistent in solving a problem, they find difficulty in resolving a problem as in [7] and [22].

\section{CONCLUSION AND SUGGESTION}

Students PSA in physics taught by PBL model were greater than CL. The results showed that there was an effect of PBL model and CL on students PSA in physics. Students PSA in physics that have high CTA were greater than students PSA in physics that have low CTA. The results showed there was an effect of CTA toward students PSA in physics. There was an interaction between PBL model and CTA in improving students PSA in physics. On PBL class, CTA give high effect on students PSA in physics. On CL class, CTA did not give effect to students PSA in physics.

PBL models gives optimum result in increasing students PSA if it applied on the students that have high CTA. Students CTA will have good interaction with PBL model because they already have the individual ability to offer new solutions or more than one solution or combination of methods to solve the problem.

\section{References}

[1] Sahyar, R.A. Sani, and T. Malau, "The Effect of Problem Based Learning (PBL) Model and Self Regulated Learning (SRL) toward Physics Problem Solving Ability (PSA) of Students at Senior High School," American Journal of Educational Research, vol. 5, pp.279-283, 2017.

[2] Research and Developement, Education and Culture Ministery, Jakarta 2015.

[3] R.I. Arends, Learning To Teach, 7th ed., Yogyakarta, Pustaka Belajar, 2013.

[4] M. Namia, Hossein, and M. Ashouri, "The Relationship Between Creativity and Academic Achievement," Procedia Social and Behavioral Sciences, vol. 11, pp.36-39, 2014.

[5] O.S. Tan, Problem Based Learning And Creativity, National Institute of Education, Nanyang Technological University, Singapore, 2009.

[6] R.A. Hawadi, S.D. Wihardjo, and M. Wiyono, Creativity, Jakarta, PT Grasindo, 2001.

[7] W. Wahyu, and N. Eli, "Using Problem Based Learning to Improve Students Creative Thinking Skills on Water Purification," AIP Conference Proceedings, 2016.

[8] E.T. Ruseffendi, Introduction To Helping Teachers Develop Their Competencies in Mathematics Teaching to Improve CBSA, Bandung, Tarsito, 1991.

[9] P. Heller, K. Ronald, and A. Scott, "Teaching Problem Solving Trough Cooperative Group, American Association of Physics Teachers, vol. 60, pp.627-636, 1992.

[10] M. Runko, G. Miller, S. Acar, and B. Cramond, "Torrance Tests of Creative Thinking as Predictors of Personal and Public Achievement: A Fifty-Year Follow-Up," Creative Research Journal, vol. 22, pp.361-368, 2010.

[11] U. Munandar, Development of creative thinking skills of Talented Children, Jakarta, Rineka Cipta, 2012.

[12] N. Wardana, "The Effect of problem-based learning and Adversity Quotient of high-level thinking ability and conceptual understanding of physics," JIPP, vol. 2, pp.56-72, 2010.

[13] S. Temel, "The effects of problem-based learning on pre-service teachers'critical thinking dispositions and perceptions of problem solving ability," South African Journal of Education, vol. 5, pp.155-165, 2014.

[14] I. Dwi, H.M. Arif, and K. Sentot, "The Effect of Problem Based Learning Model to Understanding Concepts and Problem Solving Ability,’Indonesian Journal of Physics Education, pp.8-17, 2013

[15] M.M.Ferreira, and A.R. Trudel, "The impact of problem based learning on students attitude toward science problem solving skill and sense of community in the classroom," Journal of classroom interaction, vol. 47, pp.23-30, 2012. 
[16] S. Adeyemo, "Students Ability Level and Their Competence in Problem solving Task in Physics," International Journal of Educational Research and Technology, vol. 1, 2012.

[17] T. Sindelar, The Effectiveness of Problem Based Learning In The School Science Classroom, Thesis, USA, Whichita State University, 2002.

[18] K.H. Yusof, and A.A. Aziz, "Problem Based Learning in Engineering Education: A Viable Alternative for Shaping Graduates for the 2nd Century," Conference on Engineering Education, Kuala Lumpur, pp. 1415, 2004.

[19] Sahyar, and R.K. Fitri, "The Effect of Problem-Based Learning Model (PBL) and Adversity Quotient (AQ) on Problem Solving Ability," American Journal of Educational Research, vol. 5, pp.179-183, 2017.

[20] X. Ai, "Creativity and Academic Achievement: An Investigation of Gender Differences," Creativity Research Journal, vol. 12, pp.329-337, 1999.

[21] Habibollah, R. Naderi, R. Abdullah, J. Aizan, and V.K. Sharir, "Relationship between creativity and academic achievement: A study of gender differences," Journal of American Science, vol. 6, pp.181-190, 2010 .
[22] H. Awang, and R. Ishak, "Creative Thinking Skill Approach Through Problem-Based Learning: Pedagogy and Practice in the Engineering Classroom," World Academy of Science, Engineering and Technology International, Journal of Social, Behavioral, Educational, Economic, Business and Industrial Engineering, vol. 2, 2008.

[23] M.M. Ibrahim, M.Y. Arshad, and M.S. Rosli, "The Need of an Integrated Framework for the Implementation of Blended ProblemBased Learning," International Education Studies, vol. 8, pp.33-40, 2015.

[24] E. Ersoy, and N. Baser, "The Effects of Problem Based Learning Method in Higer Education on Creative Thinking," Procedia Social and Behavioral Science, vol. 116, pp.3494-3498, 2014.

[25] J. Orozco, and T. Rosanelia, "Problem Based Learning: Effects on Critical and Creative Thinking Skills in Biology," Asian Journal of Biology Education, vol. 9, 2016.

[26] J. Talens, "Influence of Problem Based Learning on the Creative Thinking Skills of Physics Students of De La Salle Lipa," Journal of Education, Arts and Sciences, vol. 2, 2016. 